\title{
Association of ABO blood groups with craniofacial morphology among orthodontic patients of Kathmandu district
}

Sanjay Prasad Gupta ( $\approx$ sanjayagupta2000@gmail.com )

Research article

Keywords: $A B O$

Posted Date: December 27th, 2019

DOI: https://doi.org/10.21203/rs.2.14839/v2

License: (c) (1) This work is licensed under a Creative Commons Attribution 4.0 International License.

Read Full License 
The authors have withdrawn this preprint from Research Square 